\title{
Kandungan Logam Kadmium (Cd) pada Air Laut, Sedimen, dan Kerang Hijau di Perairan Tambak Lorok dan Perairan Morosari
}

\section{(The Concentration of Cd Metals on Seawater, Sediment, and Green Mussel in Tambak Lorok Waters and Morosari Waters)}

\author{
Ersan Noviansyah $^{1 \star}$, Djamar Tumpal Floranthus Lumban Batu², Isdradjad Setyobudiandi²
}

(Diterima Juli 2020/Disetujui Desember 2020)

\begin{abstract}
ABSTRAK
Logam Cd berbahaya bagi organisme kerang hijau karena dapat mengganggu fertilitas. Kerang hijau adalah organisme yang penyebarannya luas, dapat bertahan hidup pada lingkungan yang buruk, organisme menetap, cara makannya adalah filter feeder, dan digunakan sebagai bioindikator untuk memonitor konsentrasi logam Cd di perairan. Tujuan penelitian ialah mengukur konsentrasi logam Cd pada air laut, sedimen, dan daging kerang hijau di Perairan Tambak Lorok dan Morosari. Sampel air laut, sedimen, dan kerang hijau diambil dan diukur kandungan logam Cd menggunakan Spektrofotometer Serapan Atom. Hasil penelitian yang diperoleh menunjukkan bahwa konsentrasi logam Cd air laut pada bulan Mei, Juli, dan Agustus 2018 di Perairan Tambak Lorok dan Morosari secara berurutan adalah berada di bawah batas deteksi $(0,001 \mathrm{mg} / \mathrm{L}), 0,002 \mathrm{mg} / \mathrm{L}$, dan 0,002 mg/L. Konsentrasi logam Cd pada sedimen pada bulan Mei, Juli, dan Agustus di Perairan Tambak Lorok secara berurutan adalah berada di bawah batas deteksi $(0,004 \mathrm{mg} / \mathrm{kg}), 0,0023 \mathrm{mg} / \mathrm{kg}$, dan $0,0021 \mathrm{mg} / \mathrm{kg}$ dan di Perairan Morosari secara berurutan adalah berada di bawah batas deteksi $(0,004 \mathrm{mg} / \mathrm{kg}), 0,002 \mathrm{mg} / \mathrm{kg}$, dan $0,0114 \mathrm{mg} / \mathrm{kg}$. Konsentrasi logam Cd pada kerang hijau pada bulan Mei, Juli, dan Agustus di Perairan Tambak Lorok secara berurutan adalah di bawah batas deteksi 0,01 $\mathrm{mg} / \mathrm{kg}$, $0,0060 \mathrm{mg} / \mathrm{kg}$, dan $0,1277 \mathrm{mg} / \mathrm{kg}$, dan di Perairan Morosari secara berurutan adalah di bawah deteksi 0,01 $\mathrm{mg} / \mathrm{kg}$, $0,0067 \mathrm{mg} / \mathrm{kg}$, dan $0,0493 \mathrm{mg} / \mathrm{kg}$. Konsentrasi logam Cd pada air laut dan kerang hijau di Perairan Tambak Lorok dan Morosari berada di bawah baku mutu dan konsentrasi logam Cd pada air laut, sedimen, dan daging kerang hijau di Perairan Tambak Lorok dan Morosari tidak berbeda nyata.
\end{abstract}

Kata kunci: air laut, kadmium, kerang hijau, morosari, sedimen, Tambak Lorok

\section{ABSTRACT}

Cadmium metal is dangerous for green mussel organisms because it can interfere with fertility. Green mussels are organisms widely distributed, can survive in poor environments, and sedentary organisms. Green shellfish is a filter feeder and is used as a bioindicator to monitor the concentration of Cd metal in the waters. The research objective was to measure the concentration of $\mathrm{Cd}$ metal in sea water, sediment, and green mussel meat in the waters of Tambak Lorok and Morosari. The Cd metal contents of seawater, sediments, and green mussels were measured using Atomic Absorption Spectrophotometer. The results showed that Cd metal concentrations in seawater in May, July, and August 2018 in Tambak Lorok and Morosari waters were below the detection limit $(0.001 \mathrm{mg} / \mathrm{L}) ; 0.002 \mathrm{mg} / \mathrm{L}$; and $0.002 \mathrm{mg} / \mathrm{L}$, respectively. The concentrations of cadmium in sediment in May, July, and August in Tambak Lorok waters were below the detection limit $(0.004 \mathrm{mg} / \mathrm{kg}) ; 0.0023 \mathrm{mg} / \mathrm{kg}$; and $0.0021 \mathrm{mg} / \mathrm{kg}$, respectively, and in Morosari waters were below the detection limit $(0.004 \mathrm{mg} / \mathrm{kg}) ; 0.002 \mathrm{mg} / \mathrm{kg}$; and $0.0114 \mathrm{mg} / \mathrm{kg}$, respectively. Cd metal concentrations in green mussel meats in May, July, and August in Tambak Lorok waters were below the detection $\operatorname{limit}(0.01 \mathrm{mg} / \mathrm{kg}) ; 0.0060 ;$ and $0.1277 \mathrm{mg} / \mathrm{kg}$, respectively, and in Morosari water were below the detection limit $(0.01 \mathrm{mg} / \mathrm{kg}) ; 0.0067 \mathrm{mg} / \mathrm{kg}$; and $0.0493 \mathrm{mg} / \mathrm{kg}$, respectively. Cd metal concentrations in sea water and green mussels in the waters of Tambak Lorok and Morosari were below the quality standard and the concentrations of Cd metal in seawater, sediments, and green mussel meat in the waters of Tambak Lorok and Morosari were not significantly different.

Keywords: cadmium, green mussels, morosari, seawater, sediments, Tambak Lorok

1 Sekolah Pascasarjana, Program Studi Pengelolaan Sumberdaya Perairan, Institut Pertanian Bogor, Kampus IPB Darmaga, Bogor 16680

2 Departemen Manajemen Sumberdaya Perairan, Fakultas Perikanan dan IImu Kelautan, Institut Pertanian Bogor, Kampus IPB Darmaga, Bogor 16680

* Penulis Korespondensi:

Email: ersannoviansyah18@gmail.com

\section{PENDAHULUAN}

Pembangunan industri di Kota Semarang menyebabkan pencemaran perairan di wilayah kota dan sekitarnya. Perairan Tambak Lorok adalah daerah pesisir yang menjadi tempat tujuan terakhir buangan limbah yang berasal dari sungai perkotaan. Pencemaran tidak hanya berasal dari industri, namun 
juga bersumber dari perairan yang berdekatan dengan pelabuhan yang dikelilingi oleh beberapa sungai, seperti Sungai Semarang, Banjir Kanal Barat, Banjir Kanal Timur, dan Banger (Suryono \& Djunaedi 2017). Masukan limbah yang mengalir ke perairan Tambak Lorok mengandung konsentrasi logam berat $\mathrm{Cd}$ yang melebihi baku mutu yang telah ditetapkan oleh $\mathrm{KLH}$. Kandungan logam berat Cd pada air laut adalah sebesar 0,003 ppm dan di sedimen berkisar antara 2,145 hingga 7,121 ppm (Purba et al. 2014). Menurut Suryono dan Djunaedi (2017), konsentrasi logam berat $(\mathrm{Cr}, \mathrm{Cd}$, dan $\mathrm{Pb}$ ) pada air laut di perairan pelabuhan Tanjung Mas pada stasiun 1-6 berkisar antara 0,020,14 ppm untuk logam $\mathrm{Cr}$; 0,01-0,16 ppm untuk logam $\mathrm{Cd}$; dan 0,09 ppm untuk logam $\mathrm{Pb}$. Pada bulan Mei, Juni, Juli, dan Agustus rerata konsentrasi logam Cd di Perairan Tanjung Mas secara berturut-turut adalah sebesar 0,01 mg/L, 0,01 mg/L, 0,01 mg/L, dan 0,015 $\mathrm{mg} / \mathrm{L}$ (Suryono \& Djunaedi 2017). Lokasi ke-2 adalah Perairan Morosari yang merupakan daerah pesisir yang jauh dari industri yang digunakan untuk membandingkan konsentrasi logam Cd yang diduga lebih rendah daripada di Perairan Tambak Lorok. Hasil penelitian yang dilakukan oleh Putra et al. (2015) menunjukkan bahwa konsentrasi logam seng di Perairan Morosari berkisar 0,004-0,11 ppm pada saat surut dan pada saat pasang berkisar 0,003-0,008 ppm. Konsentrasi logam $\mathrm{Cr}$ pada air laut, sedimen, dan kerang hijau di muara Sungai Sayung, Desa Morosari secara berturut-turut berkisar dari tidak terdeteksi, 1,2556-1,4916 ppm, dan 0,1278-0,1617 ppm (Suprapti 2008).

Kerang hijau hidup di perairan litoral dan sublitoral hingga kedalaman 15 meter, dan kerang ini hidup menempel pada substrat yang keras, seperti kayu, bambu, dan waring dengan bantuan bysus. Hewan ini merupakan biota perairan yang hidup menetap di dasar perairan, mencari makan dengan cara menyaring air dan dapat bertahan hidup dalam kondisi perairan yang buruk, dan mampu mengakumulasi logam berat pada lingkungan tercemar (Hutagalung 2001), dan dapat berkembang biak pada lingkungan dengan tekanan ekologis yang tinggi tanpa mengalami gangguan (Cappenberg 2008). Sifat kerang hijau yang menetap dapat digunakan untuk memonitor konsentrasi logam Cd di Perairan. Menurut Sudaryanto et al. (2005) dan $\mathrm{Ng}$ \& Wang (2007), kerang hijau merupakan bioindikator yang digunakan untuk memonitor senyawa-senyawa beracun di lingkungan perairan laut karena distribusi penyebarannya luas, mempunyai sifat hidup menetap, mempunyai toleransi yang luas terhadap salinitas, serta tahan terhadap tekanan lingkungan dan akumulasi berbagai bahan kimia yang tinggi. Hasil penelitian Cordova et al. (2011) melaporkan bahwa kerang hijau yang berumur 1-2 bulan, 3-4 bulan, dan 5-6 bulan secara berturut-turut mengandung logam berat sebesar 0,070 $\mu \mathrm{g} / \mathrm{g}$ bk, $0,0778 \mu \mathrm{g} / \mathrm{g}$, dan $0,152 \mu \mathrm{g} / \mathrm{g}$. Penelitian ini bertujuan untuk mengukur konsentrasi logam Cd pada air laut, sedimen, dan daging kerang hijau di Perairan Tambak
Lorok dan Morosari. Kerang hijau adalah organisme yang penyebarannya luas, dapat bertahan hidup pada lingkungan yang buruk, organisme menetap, cara makan kerang hijau ialah filter feeder, dan digunakan sebagai bioindikator untuk memonitor perairan.

\section{METODE PENELITIAN}

Penelitian dilakukan pada bulan Mei, Juli, dan Agustus 2018 di Perairan Tambak Lorok, Kota Semarang dan Perairan Morosari, Kota Demak. Pengambilan data dilakukan di kedua perairan yang terdiri atas 2 stasiun. Pengujian logam Cd dilakukan di Balai Besar Teknologi Pencegahan Pencemaran Industri dan Balai Laboratorium Kesehatan dan Pengujian Alat Kesehatan Kota Semarang.

\section{Bahan dan Alat}

Bahan yang digunakan dalam penelitian ini ialah kerang hijau (250 g), $\mathrm{HNO}_{3} 65 \%$, dan $\mathrm{HCl} 6 \mathrm{M}$. Alat yang digunakan ialah Van dorn, Ekman grab, blender, Spektrofotometer Serapan Atom (Shimadzu AA 6200), botol polystyrene, hot plate, timbangan analitik, tungku pengabuan, mikropipet, oven, dan microwave.

\section{Penyiapan dan Pengukuran Logam Berat Cd Dalam Air Laut}

Sampel air laut diambil dengan menggunakan Van dorn pada kedalaman $200 \mathrm{~cm}$ (Perairan Tambak Lorok) dan $100 \mathrm{~cm}$ (Perairan Morosari) dari permukaan laut. Selanjutnya, sampel air dipindahkan ke botol sampel sebanyak $500 \mathrm{~mL}$. Analisis logam Cd pada sampel air merujuk pada metode APHA 2012. Sampel air laut yang diperoleh disiapkan untuk dianalisis logam Cd. Sampel disaring dengan kertas saring ukuran pori 0,45 mikrometer dan ditambahkan $5 \mathrm{~mL} \mathrm{HNO}_{3}$ hingga $\mathrm{pH}$ mencapai 2, kemudian dimasukkan ke dalam erlenmeyer sebanyak $100 \mathrm{~mL}$. Kemudian ditambahkan $5 \mathrm{~mL} \mathrm{HNO}_{3}$ dan ditutup dengan corong. Setelah itu, larutan sampel dipanaskan dengan microwave pada temperatur $160^{\circ} \mathrm{C}$ sampai sisa volume $15 \mathrm{~mL}$. Sampel dipindahkan ke dalam labu ukur $50 \mathrm{~mL}$ dan ditambah akuades sampai tepat tanda tera kemudian dihomogenkan. Selanjutnya diukur dengan spektrofotometer serapan atom (teknik furnace) dengan gelombang resonansi 228,72 nm.

\section{Penyiapan dan Pengukuran Logam Berat Cd Dalam Sedimen}

Sampel sedimen diambil menggunakan Ekman grab sebanyak tiga kali pengulangan setiap sampling, kemudian dimasukkan ke dalam plastik sebanyak $1 \mathrm{~kg}$ untuk dianalisis logam Cd. Analisis logam Cd pada sampel sedimen merujuk pada metode APHA 2012. Sampel yang diperoleh dikeringkan dalam oven pada temperatur $105^{\circ} \mathrm{C}$, kemudian dihaluskan dan diayak dengan ayakan $150 \mu \mathrm{m}$. Sampel ditimbang sebanyak $5 \mathrm{~g}$ kemudian dipindahkan ke erlenmeyer $250 \mathrm{~mL}$. Selanjutnya sampel ditambahkan $\mathrm{HNO}_{3}$ sebanyak 5 
$\mathrm{mL}$ dan akuades $50 \mathrm{~mL}$, kemudian didestruksi dalam heat mantel hingga diperoleh larutan jernih sampai volumenya menjadi $10 \mathrm{~mL}$. Sampel disaring dengan kertas saring Whatman No. 41 dan hasil saringan diencerkan dengan aquabides hingga $50 \mathrm{~mL}$. Kadar logam Cd sampel diukur dengan menggunakan Spektrofotometer Serapan Atom pada gelombang resonansi $228,72 \mathrm{~nm}$.

\section{Penyiapan dan Pengukuran Logam Berat Cd Dalam Kerang Hijau}

Kerang hijau diambil sebanyak 200 ekor dari bambu tempat kerang menempel. Kemudian sampel kerang dimasukkan ke dalam plastik untuk dibawa ke laboratorium. Analisis logam $\mathrm{Cd}$ pada sampel daging kerang hijau merujuk pada metode APHA 2012. Daging dipisah dari cangkang kemudian dihaluskan dengan blender hingga homogen dan ditempatkan dalam wadah polystyrene. Sampel daging kerang basah ditimbang sebanyak $5 \mathrm{~g}$ dalam cawan porselen. Sampel diuapkan di atas hot plate pada suhu $100^{\circ} \mathrm{C}$, kemudian sampel dimasukkan ke dalam tungku di pengabuan dan ditutup separuh permukaan. Suhu tungku pengabuan dinaikkan secara bertahap mulai dari $100^{\circ} \mathrm{C}$ setiap 30 menit hingga mencapai $450^{\circ} \mathrm{C}$ dan dipertahankan selama 18 jam. Sampel dikeluarkan dari tungku pengabuan dan didinginkan pada suhu kamar, ditambahkan $1 \mathrm{~mL} \mathrm{HNO}_{3} 65 \%$, kemudian diuapkan di atas hot plate pada suhu $100^{\circ} \mathrm{C}$ sampai kering. Setelah kering, dimasukkan kembali ke dalam tungku pengabuan dan suhu dinaikkan secara bertahap mulai $100^{\circ} \mathrm{C}$ setiap 30 menit hingga mencapai $450^{\circ} \mathrm{C}$ dan dipertahankan selama 3 jam. Sampel didinginkan pada suhu ruang kemudian ditambahkan $5 \mathrm{~mL} \mathrm{HCl} 6 \mathrm{M}$ dan selanjutnya ditambahkan $10 \mathrm{~mL} \mathrm{HNO}$ 3 $0,1 \mathrm{M}$ dan didinginkan pada suhu ruang selama 1 jam. Sampel dipindahkan ke dalam labu takar polypropylene $50 \mathrm{ml}$ dan ditambahkan larutan matrix modifier, ditepatkan sampai tanda batas dengan $\mathrm{HNO}_{3}$ 0,1 $\mathrm{M}$, kemudian diukur dengan AAS dengan gelombang resonansi 228,72 $\mathrm{nm}$.

\section{Analisis Data}

Data yang diperoleh, yaitu konsentrasi logam $\mathrm{Cd}$ pada air laut ditampilkan dalam bentuk tabel dan konsentrasi logam Cd pada sedimen dan kerang hijau ditampilkan dalam bentuk grafik.

\section{HASIL DAN PEMBAHASAN}

\section{Konsentrasi Logam Cd air laut}

Konsentrasi logam Cd air laut dari kedua perairan yang telah dianalisis disajikan pada Tabel 1. Sampel air laut yang berasal dari Perairan Tambak Lorok dan Morosari pada bulan Mei dianalisis kandungan logam Cd di Balai Besar Teknologi Pencegahan Pencemaran Industri, Kota Semarang. Nilai yang diperoleh sebesar $<0,001 \mathrm{mg} / \mathrm{L}$, sementara batas deteksi adalah sebesar $0,001 \mathrm{mg} / \mathrm{L}$. Data logam Cd pada bulan Mei tidak ditampilkan pada Tabel 1. Sementara itu, sampel air laut pada bulan Juli dan Agustus dianalisis kandungan logam Cd di Balai Laboratorium Kesehatan dan Pengujian Alat Kesehatan Kota Semarang. Data yang diperoleh ditampilkan pada Tabel 1 . Tabel 1 menunjukkan logam $\mathrm{Cd}$ air laut yang berasal dari kedua perairan tidak ada perubahan dan masih di bawah baku mutu. Baku mutu logam Cd air laut yang telah ditetapkan oleh KLH adalah sebesar $0,01 \mathrm{mg} / \mathrm{L}$. Konsentrasi logam Cd di perairan Tambak Lorok dan Morosari pada bulan Mei adalah yang paling rendah. Konsentrasi logam $\mathrm{Cd}$ yang rendah di lokasi tersebut diduga karena pada bulan Mei masih terjadi hujan sehingga menurunkan salinitas dan terjadi proses pengenceran. Data dari BMKG pada tanggal 8 Mei 2018 menunjukkan curah hujan sebesar $2 \mathrm{~mm}$. Penelitian pada bulan November dan Desember 2013 yang dilakukan oleh Purba et al. (2014) menunjukkan bahwa pada bulan November, konsentrasi logam Cd terlarut tidak terdeteksi dan pada bulan Desember berkisar antara tidak terdeteksi sampai $0,003 \mathrm{mg} / \mathrm{L}$. Data curah hujan dari BMKG pada tanggal 7 November dan 7 Desember 2013 secara berturut-turut adalah sebesar 7,0 mm dan $8,0 \mathrm{~mm}$. Faktor yang membantu proses pengenceran adalah arus, pasang surut, dan gelombang. Data dari Copernicus Marine Environment Monitoring Service (2019) menunjukkan nilai kecepatan arus pada bulan Mei 2018 di perairan Tambak Lorok adalah sebesar $0,05 \mathrm{~m} / \mathrm{s}$ dan nilai kecepatan arus dan gelombang pada bulan Mei 2018 di perairan Morosari adalah sebesar $0,03 \mathrm{~m} / \mathrm{s}$ dan 0,21 m. Menurut Moriarty (1988), siklus pasang surut menyebabkan kuantitas logam berat pada satu satuan massa air akan menurun. Penelitian yang dilakukan oleh Koropitan dan Cordova (2017) menunjukkan konsentrasi logam $\mathrm{Cd}$ air laut di Teluk Jakarta adalah sebesar 0,014-0,064 mg/L.

Pada bulan Juli, konsentrasi logam Cd di kedua perairan adalah sebesar 0,002 $\mathrm{mg} / \mathrm{L}$. Diduga, kondisi perairan yang menurun, seperti curah hujan yang menurun mengakibatkan proses pengenceran juga menurun. Data dari BMKG pada tanggal 18 Juli 2018, curah hujan adalah sebesar 0,4 mm. Faktor lain adalah arus, pasang surut, dan gelombang yang rendah menyebabkan logam $\mathrm{Cd}$ yang masuk ke perairan tersedia lebih banyak dari pada bulan Mei. Data dari Copernicus Marine Environment Monitoring Service (2019) menunjukkan nilai kecepatan arus bulan Juli

Tabel 1 Konsentrasi logam Cd pada air laut di Perairan Tambak Lorok dan Perairan Morosari $(n=3)$

\begin{tabular}{cclc}
\hline Lokasi & Batas deteksi & Bulan & Logam Cd $(\mathrm{mg} / \mathrm{L})$ \\
\hline Perairan Tambak Lorok & 0,002 & Juli & 0,002 \\
& 0,002 & Agustus & 0,002 \\
Perairan Morosari & 0,002 & Juli & 0,002 \\
& 0,002 & Agustus & 0,002 \\
\hline
\end{tabular}


2018 di perairan Tambak Lorok dan Morosari secara berturut-turut adalah sebesar 0,003 dan 0,02 m/s. Penelitian yang dilakukan oleh Riani et al. (2017) menunjukkan konsentrasi logam Cd air laut di Pulau Panggang dan Pulau Karya adalah sebesar 0,0006 dan $0,001 \mathrm{mg} / \mathrm{L}$.

Konsentrasi logam Cd air laut di perairan Tambak Lorok dan Morosari pada bulan Agustus adalah sebesar 0,002 mg/L. Data dari Copernicus Marine Environment Monitoring Service (2019) menunjukkan bahwa nilai kecepatan arus pada bulan Agustus 2018 di perairan Tambak Lorok dan Morosari secara berturut-turut adalah sebesar 0,004 dan 0,02 m/s. Nilai logam $\mathrm{Cd}$ di kedua perairan lebih rendah dibandingkan dengan nilai logam $\mathrm{Cd}$ air laut di pelabuhan Tanjung Mas pada tahun 2017 yang berkisar antara 0,01-0,16 ppm (Suryono \& Djunaedi 2017), sementara konsentrasi logam $\mathrm{Cd}$ terlarut di Teluk Jakarta berkisar antara 0,001-0,003 ppm (Kusuma et al. 2015).

Sumber-sumber logam $\mathrm{Cd}$ yang memasuki perairan Tambak Lorok dan perairan Morosari berasal dari industri dan korosi cat kapal nelayan yang menyebabkan kadmium terlepas memasuki badan perairan. Selain itu, logam Cd juga digunakan dalam penstabil panas pada plastik sehingga pada saat pembakaran sampah plastik, logam Cd terlepas ke udara dan dapat memasuki badan perairan melalui presipitasi. Selain itu, perairan Tambak Lorok yang dekat dengan Pelabuhan Tanjung Mas diduga mendapat masukan logam Cd dari ballast water yang dibuang ke perairan. Sumber logam Cd yang terdapat di perairan bisa secara alamiah (proses pelapukan; vulkanik; ekstraksi, dan pengolahan logam $\mathrm{Zn}$ dan $\mathrm{Pb}$ menghasilkan $\mathrm{Cd}$, dan pembakaran batu bara dan fosil yang menghasilkan Cd) dan secara antropogenik (pelapis cat, sebagai stabilisator, baterai $\mathrm{Ni}-\mathrm{Cd}$, electroplatting, dan pelapis PVC) (Bradl 2005; Wang et al. 2010).

\section{Konsentrasi Logam Cd pada Sedimen}

Pengujian logam $\mathrm{Cd}$ sampel sedimen pada bulan Mei dilakukan di Balai Besar Teknologi Pencegahan Pencemaran Industri Kota Semarang, sedangkan pengujian sedimen pada bulan Juli dan Agustus dilakukan di Balai Laboratorium Kesehatan dan Pengujian Alat Kesehatan Kota Semarang. Analisis logam $\mathrm{Cd}$ di sedimen perairan Tambak Lorok dan Morosari pada bulan Mei diperoleh nilai sebesar < $0,004 \mathrm{mg} / \mathrm{kg}$ di mana nilai tersebut berada di bawah batas deteksi, yaitu $0,004 \mathrm{mg} / \mathrm{kg}$. Data pada bulan Mei tidak ditampilkan pada Tabel 2. Konsentrasi logam $\mathrm{Cd}$ di sedimen perairan Tambak Lorok dan Morosari pada bulan Juli secara berturut-turut adalah sebesar 0,0023 dan $0,002 \mathrm{mg} / \mathrm{kg}$, sementara pada bulan Agustus secara berturut-turut adalah sebesar 0,0021 dan $0,0114 \mathrm{mg} / \mathrm{kg}$. Hasil penelitian yang dilakukan oleh Azhar et al. (2012) menunjukkan bahwa kandungan logam Cd pada air laut di Perairan Wedung Demak adalah pada level tidak terdeteksi sampai 0,01 ppm.

Hal yang mempengaruhi logam $\mathrm{Cd}$ yang rendah adalah logam Cd yang mudah terlepas ke kolom air yang ada pada arus dan oksigen di dasar perairan. Menurut $\mathrm{Yu}$ et al. (2001), ketersediaan logam berat di sedimen bergantung pada perbedaan bentuk geokimia, yang ditentukan oleh kapasitas mobilisasi dan bioavailability.

Rerata konsentrasi logam $\mathrm{Cd}$ di sedimen perairan Tambak Lorok pada bulan Juli adalah sebesar 0,0023 $\mathrm{mg} / \mathrm{kg}$, sementara di perairan Morosari adalah sebesar $0,002 \mathrm{mg} / \mathrm{kg}$. Arus yang rendah serta logam Cd yang terikat dengan bahan organik dan tss (total suspended solid adalah bahan-bahan tersuspensi yang berdiameter $>1 \mu \mathrm{m}$ yang terdiri atas lumper, tanah liat, pasir halus, serta jasad renik) mengakibatkan logam Cd cepat mengendap di dasar perairan. Data dari Copernicus Marine Environment Monitoring Service (2019) menunjukkan nilai kecepatan arus pada bulan Juli 2018 di perairan Tambak Lorok dan Morosari secara berturut-turut adalah sebesar 0,003 dan 0,02 $\mathrm{m} / \mathrm{s}$. Menurut Afriansyah et al. (2010) logam berat di perairan berikatan dengan ligan, partikel tersuspensi, bahan organik, bersama komponen mengendap dalam sedimen. Penyerapan $\mathrm{Cd}$ dipengaruhi oleh $\mathrm{pH}$ dan kekuatan ion dan kation yang bisa berubah (Bradl 2005). Menurut Riani et al. (2017), rerata konsentrasi logam Cd sedimen pada kedua perairan lebih rendah dibandingkan di Pulau Panggang dan Pulau Karya Kepulauan Seribu pada bulan Juli yang secara berturut-turut adalah sebesar 0,30 dan $3,90 \mathrm{mg} / \mathrm{kg}$.

Rerata konsentrasi logam Cd pada bulan Agustus di perairan Tambak Lorok adalah sebesar 0,0021 $\mathrm{mg} / \mathrm{kg}$. Pelepasan logam $\mathrm{Cd}$ ke badan air dipengaruhi oleh arus dan oksigen yang terdapat di dasar perairan yang menyebabkan logam $\mathrm{Cd}$ terlepas ke badan perairan. Data dari Copernicus Marine Environment Monitoring Service (2019) menunjukkan nilai kecepatan arus pada bulan Agustus 2018 di perairan Tambak Lorok adalah sebesar $0,004 \mathrm{~m} / \mathrm{s}$. Jenis sedimen juga mempengaruhi pelepasan logam Cd dari sedimen ke badan air. Fraksi geokimia yang menyusun sedimen perairan yang mampu mengarbsorpsi dan memobilisasi logam berat ialah tanah liat, lumpur, pasir, bahan organik, oksidasi (hasil oksidasi besi) mangan, alumunium dan silikat, karbonat, dan sulfida kompleks (Afriyansyah et al. 2010). Konsentrasi logam $\mathrm{Cd}$ di sedimen perairan Morosari adalah sebesar $0,0114 \mathrm{mg} / \mathrm{kg}$.

Tabel 2 Logam Cd pada sedimen dan daging kerang hijau di perairan Tambak Lorok dan perairan Morosari $(n=3)$

\begin{tabular}{rlcc}
\hline Lokasi & \multicolumn{1}{c}{ Bulan } & Logam Cd sedimen $(\mathrm{mg} / \mathrm{kg})$ & Logam Cd daging $\mathrm{kerang} \mathrm{hijau}(\mathrm{mg} / \mathrm{kg})$ \\
\hline Tambak Lorok & Juli & 0,0023 & 0,0060 \\
\multirow{2}{*}{ Morosari } & Agustus & 0,0021 & 0,1280 \\
& Juli & 0,0020 & 0,0067 \\
& Agustus & 0,0114 & 0,0493 \\
\hline
\end{tabular}


Rerata konsentrasi logam Cd di sedimen perairan Tambak Lorok lebih rendah jika dibandingkan dengan rerata konsentrasi logam $\mathrm{Cd}$ di sedimen pelabuhan Tanjung Mas yang diteliti oleh Purba et al. (2014) pada bulan November dan Desember 2013 yang berkisar antara $2,145-7,121 \mathrm{mg} / \mathrm{kg}$ yang dikategorikan sebagai tercemar ringan. Selanjutnya rerata konsentrasi logam $\mathrm{Cd}$ di sedimen perairan Morosari lebih rendah dibandingkan di sedimen perairan Teluk Jakarta yang berkisar antara 0,08-0,47 ppm (Rochyatun \& Rozak 2007).

Tabel 2 menunjukkan rerata konsentrasi logam $\mathrm{Cd}$ di sedimen Perairan Tambak Lorok antara bulan Juli dan Agustus yang tidak berbeda nyata, dan hal yang sama juga terjadi di Perairan Morosari. Selanjutnya antara kedua perairan juga menunjukkan nilai yang tidak berbeda nyata.

Konsentrasi logam Cd pada sedimen di kedua perairan masih di bawah ambang batas yang ditetapkan oleh National Sediment Quality Survey USEPA, yaitu pada rentang 0,65-2,49 ppm. Sifat logam berat sangat mudah mengikat bahan organik dan mengendap di dasar perairan. Fraksi dalam sedimen adalah logam berat fraksi resistans (tidak dapat diserap oleh organisme) dan logam berat fraksi nonresistans (yang dapat diserap dan diakumulasi oleh organisme). Logam Cd pada sedimen dijumpai dalam fraksi organik (berasosiasi dengan Mn oksida), easy reducible (berasosiasi dengan $\mathrm{Fe}$ oksida), dan residual. Logam Cd dalam sedimen berikatan dengan fraksi easy reducible dan reducible dibandingkan logam Cd dalam fraksi residual yang tidak berikatan dengan bahan yang dapat terurai, sehingga fraksi reducible berperan sebagai reservoir yang penting bagi keberadaan Cd dalam sedimen (Thomas \& BendellYoung 1998).

\section{Konsentrasi Logam Cd pada Daging Kerang Hijau}

Analisis logam Cd pada sampel daging kerang hijau pada bulan Mei dilakukan di Balai Besar Teknologi Pencegahan Pencemaran Industri Kota Semarang. Untuk sampel yang diambil pada bulan Juli dan Agustus, analisis logam $\mathrm{Cd}$ dilakukan di Balai Laboratorium Kesehatan dan Pengujian Alat Kesehatan Kota Semarang. Konsentrasi logam Cd pada daging kerang hijau di Perairan Tambak Lorok pada bulan Mei, Juli, dan Agustus secara berturut-turut adalah tidak terdeteksi (di bawah batas deteksi 0,01 $\mathrm{mg} / \mathrm{kg}$ ); 0,006; dan $0,128 \mathrm{mg} / \mathrm{kg}$. Sementara rerata konsentrasi logam $\mathrm{Cd}$ pada daging kerang hijau di perairan Morosari pada bulan Mei, Juli, dan Agustus secara berturut-turut adalah tidak terdeteksi (di bawah batas deteksi $0,01 \mathrm{mg} / \mathrm{kg}$ ); 0,0067; dan 0,0493 mg/kg. Data pada bulan Mei tidak ditampilkan pada Tabel 2 . Tabel 2 menunjukkan bahwa rerata konsentrasi logam Cd pada daging di perairan Tambak Lorok mengalami peningkatan dari bulan Juli hingga Agustus. The Codex Committe on Food Addictive and Contaminants mengatakan bahwa kandungan maksimum logam $\mathrm{Cd}$ dalam makanan adalah sebesar $0,4 \mathrm{mg} / \mathrm{kg}$ (Arao \& Ishikawa 2006).

Pada bulan Mei, kandungan logam Cd pada daging kerang hijau di perairan Tambak Lorok dan Morosari tidak terdeteksi yang diduga karena ketersediaan logam Cd yang rendah. Ketersediaan logam Cd yang sedikit di perairan menyebabkan kerang hijau hanya sedikit menyerap logam $\mathrm{Cd}$ sehingga tidak terdeteksi pada saat dianalisis di laboratorium. Ketersediaan logam $\mathrm{Cd}$ yang rendah diduga karena adanya proses dilusi (pengenceran), yang disebabkan oleh curah hujan yang memasuki perairan mengakibatkan penurunan salinitas. Selain itu, arus aliran air membantu memindahkan logam Cd dari perairan yang berkonsentrasi $\mathrm{Cd}$ tinggi ke perairan yang berkonsentrasi Cd rendah. Menurut Munce (1990), konsentrasi logam $\mathrm{Cd}$ yang rendah bisa disebabkan oleh pergerakan air laut yang dinamis yang dipengaruhi oleh angin, arus, gelombang, dan pasang surut sehingga terjadi proses pengenceran.

Kandungan logam Cd yang diserap oleh kerang hijau di kedua perairan pada bulan Juli secara berturutturut adalah sebesar 0,0060 dan $0,0067 \mathrm{mg} / \mathrm{kg}$. Penelitian yang dilakukan oleh Eshmat (2014) mengatakan bahwa konsentrasi logam Cd dalam tubuh kerang hijau pada bulan Juli di perairan Ngemboh berkisar antara $0,012-0,129 \mathrm{mg} / \mathrm{kg}$. Logam yang masuk ke dalam tubuh kerang akan tertimbun di dalam tubuh kerang hijau dan penimbunan logam Cd dalam tubuh kerang sering disebut dengan istilah bioakumulasi. Penelitian yang dilakukan oleh Sasikumar et al. (2011) mengatakan adanya korelasi positif logam $\mathrm{Cd}$ di jaringan kerang dengan ketersediaan logam $\mathrm{Cd}$ yang tinggi di perairan.

Pada bulan Agustus, kandungan logam Cd dalam tubuh kerang hijau di perairan Tambak Lorok mengalami peningkatan sebesar $0,1217 \mathrm{mg} / \mathrm{kg}$. Hal ini terjadi karena ketersediaan logam $\mathrm{Cd}$ yang tinggi sehingga banyak yang bisa diserap oleh kerang hijau. Sementara pada bulan Agustus, kerang hijau yang berasal dari perairan Morosari menyerap logam Cd sebesar $0,0493 \mathrm{mg} / \mathrm{kg}$, yang tidak berbeda nyata dibandingkan dengan pengamatan pada bulan Juli. Jika kerang hijau menyerap logam $\mathrm{Cd}$ secara terus menerus maka konsentrasi logam $\mathrm{Cd}$ dalam tubuh kerang hijau akan lebih tinggi daripada di perairan. Biokonsentrasi adalah penyerapan bahan kimia melalui insang organisme dan kemudian konsentrasi kontaminan kimia dalam jaringan tubuh organisme melebihi konsentrasi lingkungan (Gobas et al. 1999). Penyerapan logam $\mathrm{Cd}$ oleh kerang hijau lebih besar daripada yang dikeluarkan dari tubuh maka akan terjadi penumpukan logam Cd. Logam Cd yang memasuki tubuh kerang hijau juga merupakan bioakumulasi, yaitu proses di mana bahan kimia dalam tubuh organisme meningkat di setiap tahapan dalam rantai makanan (Gobas et al. 1999).

Ketersediaan logam Cd yang tinggi di perairan dapat meningkatkan konsentrasi logam $\mathrm{Cd}$ di dalam tubuh kerang hijau. Peningkatan logam Cd disebabkan 
oleh penyerapan yang dilakukan oleh kerang hijau secara terus-menerus sehingga logam $\mathrm{Cd}$ tertimbun di dalam tubuh kerang hijau. Logam berat yang masuk ke tubuh organisme dapat melalui oral, inhalasi, atau dermal (Indirawati 2017). Kadmium pada lingkungan diserap oleh organisme dalam bentuk $\left(\mathrm{Cd}^{2+}\right)$ dan berasosiasi dengan $\left(\mathrm{Cl}^{-}\right)$. Logam $\mathrm{Cd}$ yang memasuki tubuh akan berikatan dengan darah dan terikat pada sel darah dan albumin. Penyerapan logam $\mathrm{Cd}$ oleh kerang bergantung pada ukuran dan jenis kelamin. Menurut Suprapto et al. (2018) logam berat yang tinggi di dalam tubuh organisme bergantung pada kondisi fisiologis (penyerapan dan proses ekskresi).

Hasil penelitian yang dilakukan oleh Purba et al. (2014) menunjukkan bahwa konsentrasi logam Cd dalam tubuh kerang hijau yang berasal dari pelabuhan Tanjung Mas pada bulan November dan Desember 2013 adalah pada level tidak terdeteksi (di bawah batas deteksi SSA sebesar 0,01 mg/kg). Penelitian lain yang dilakukan oleh Astudillo et al. (2002) menunjukkan bahwa konsentrasi logam Cd pada kerang hijau di Pesisir North, Venezuela adalah sebesar $0,02 \mu / g$ bobot basah dan di Teluk Gulf, Trinidad adalah sebesar 0,24 $\mu \mathrm{g} / \mathrm{g}$ bobot basah.

\section{Hubungan Logam Cd pada Air Laut, Sedimen, dan Daging Kerang}

Pada bulan Mei, ketersediaan konsentrasi logam Cd di perairan Tambak Lorok dan Morosari adalah rendah, yang dapat dilihat dari konsentrasi logam Cd pada air laut, sedimen, dan daging kerang hijau yang tidak terdeteksi. Ketersediaan logam $\mathrm{Cd}$ yang rendah adalah akibat dari proses pengenceran karena curah hujan. Selain itu, logam Cd pada kolom perairan berpindah akibat adanya arus sehingga sedikit logam Cd yang mengendap dan diserap oleh kerang hijau. Faktor lain ialah gelombang dan pasang surut. Kondisi perairan yang buruk di mana arus, pasang surut, dan gelombang yang besar mengakibatkan terjadinya proses flushing rate atau pencucian dan waktu tinggal logam Cd menjadi sangat singkat.

Konsentrasi logam Cd tertinggi antara air laut, sedimen, dan daging kerang hijau di perairan Tambak Lorok pada bulan Juli adalah pada daging kerang hijau. Logam Cd pada daging kerang hijau adalah sebesar $0,0060 \mathrm{mg} / \mathrm{kg}$, sementara pada air laut dan sedimen secara berturut-turut adalah sebesar $0,002 \mathrm{mg} / \mathrm{L}$ dan $0,0023 \mathrm{mg} / \mathrm{kg}$. Apabila konsentrasi logam Cd pada daging kerang hijau dibagi dengan konsentrasi pada air laut dan sedimen maka nilai yang dihasilkan tidak jauh berbeda, yaitu sebesar 3 dan 2,6 sehingga dapat disimpulkan bahwa kerang hijau lebih banyak menyerap logam Cd dari air laut. Konsentrasi logam Cd tertinggi pada perairan Morosari ialah pada daging kerang hijau, yaitu sebesar 0,0067 mg/kg. Logam Cd yang terserap oleh kerang hijau lebih banyak berasal dari air laut. Nilai konsentrasi logam Cd pada daging kerang hijau dibagi dengan konsentrasi logam Cd pada air laut lebih tinggi dibandingkan dengan hasil bagi antara konsentrasi logam Cd pada daging kerang hijau dengan konsentrasi logam Cd pada sedimen.

Pada bulan Agustus, konsentrasi tertinggi logam Cd di perairan Tambak Lorok ditemukan pada daging kerang hijau. Logam Cd lebih banyak diserap oleh kerang hijau dari air laut dibandingkan dari sedimen. Konsentrasi logam Cd di sedimen pada bulan Juli ke Agustus berkurang sebesar 0,0002 mg/kg. Menurut $\mathrm{Yu}$ et al. (2010), logam (bentuk atau pengikatan atom) di sedimen ialah ion bebas dan berikatan dengan karbonat di mana bentuk tersebut adalah labil sehingga dapat lepas ke perairan dan mudah diserap oleh organisme. Faktor lain yang membuat logam Cd mudah terlepas dari sedimen adalah jenis sedimen yang mudah mengikat logam dan melepas logam. Nilai kandungan logam $\mathrm{Cd}$ di perairan Morosari terbesar ialah pada daging kerang hijau yang diikuti oleh kandungan pada sedimen dan air laut. Logam Cd lebih banyak diserap oleh kerang hijau dari air laut karena nilai konsentrasi logam air laut lebih rendah daripada kandungan sedimen. Logam Cd yang masuk ke perairan mengalami waktu tinggal yang cukup lama di mana kondisi perairan tidak buruk, seperti arus dan gelombang yang rendah sehingga logam Cd yang mengendap ke perairan mencapai sebesar 0,0114 $\mathrm{mg} / \mathrm{kg}$. Ketersediaan logam Cd di kolom perairan akan diserap oleh kerang hijau sehingga meningkatkan logam Cd di tubuh kerang hijau. Terjadinya biokonsentrasi di mana konsentrasi logam Cd pada tubuh kerang hijau lebih tinggi dibandingkan dengan pada lingkungan. Organisme juga mengalami bioakumulasi di mana konsentrasi logam $\mathrm{Cd}$ mengalami peningkatan seiring dengan perjalanan waktu karena terjadi penimbunan bahan tersebut di tubuh karena logam Cd yang keluar dari tubuh (ekskresi) lebih sedikit dibandingkan dengan yang masuk ke tubuh kerang hijau.

Penelitian yang dilakukan oleh Purba et al. (2014) pada bulan November 2013 di pelabuhan Tanjung Mas menunjukkan bahwa kandungan logam Cd pada sedimen lebih tinggi dibandingkan dengan kandungan pada air laut dan daging kerang hijau. Konsentrasi logam Cd air laut, sedimen, dan daging kerang hijau secara berturut-turut adalah sebesar tidak terdeteksi (di bawah batas deteksi SSA sebesar 0,001 mg/L)0,003 $\mathrm{mg} / \mathrm{L} ; 2,145 \mathrm{mg} / \mathrm{kg}$; dan tidak terdeteksi (di bawah batas deteksi sebesar 0,01 mg/kg). Hasil penelitian yang dilakukan oleh Falah et al. (2018) menunjukkan bahwa konsentrasi logam $\mathrm{Cu}$ dan $\mathrm{Pb}$ di air, sedimen, dan kerang hijau di muara sungai Morosari secara berturut-turut berkisar antara 0,016$0,063 \mathrm{mg} / \mathrm{L}(\mathrm{Cu})$ dan 0,224-0,351 mg/L (Pb), < 0,001$0,139 \mathrm{mg} / \mathrm{kg}(\mathrm{Cu})$ dan 1,139-3,070 mg/kg (Pb), dan 3,761-30,167 mg/kg (Cu) dan 2,790-26,667 mg/kg (Pb). Kondisi perairan juga mempengaruhi keberadaan logam Cd di perairan, seperti arus, gelombang, dan pasang surut. Faktor lain yang mempengaruhi adalah $\mathrm{pH}$ dan salinitas. Menurut Wang et al. (2010) faktor lain yang mempengaruhi ketersediaan kadmium di 
perairan termasuk salinitas, $\mathrm{pH}$, dissolved organic carbon, dan kesadahan (kalsium dan magnesium).

\section{KESIMPULAN}

Konsentrasi logam Cd pada air laut dan pada daging kerang hijau di Perairan Tambak Lorok dan Morosari berada di bawah baku mutu yang ditetapkan. Konsentrasi logam Cd pada air laut, sedimen, dan daging kerang hijau di Perairan Tambak Lorok dan Morosari tidak berbeda nyata.

\section{DAFTAR PUSTAKA}

Afriyansyah A, Prartono T, Arifin Z. 2010. Konsentrasi kadmium $(\mathrm{Cd})$ dan tembaga $(\mathrm{Cu})$ dalam air, seston, kerang dan fraksinasinya dalam sedimen di Perairan Delta Berau, Kalimantan Timur. IImu Kelautan. 2: 436-446.

[APHA] American Public Health Association. 2012. Standard Method for The Examination of Water and Waste Water. 22 ${ }^{\text {th }}$ edition. American Public Health Association. Washington DC (US): Environmental Protection Agency Press.

Arao T, Ishikawa S. 2006. Genotype differencess in cadmium concentration and distribution of soybean and rice. Japan Agricultural Research Quarterly. 40 : 21-30. https://doi.org/10.6090/jarq.40.21

Astudillo LR, Yen IC, Agard J, Bekele I, Hubbard R. 2002. Heavy metal in green mussel (Perna viridis) and oyster (Crassostrea sp.) from Trinidad and Venezuela. Archieves of Environmental Contamination and Toxicology. 42: 410-415. https://doi.org/10.1007/s00244-001-0044-z

Azhar H, Widowati I, Suprijanto J. 2012. Studi kandungan logam berat $\mathrm{Pb}, \mathrm{Cu}, \mathrm{Cd}, \mathrm{Cr}$ pada Kerang Simping (Amusium pleuronectes), air dan sedimen di Perairan Wedung, Demak serta analisis Maximum Tolerable Intake pada manusia. Journal of Marine Research. 1(2): 35-44.

[BMKG] Badan Meteorologi, Klimatologi dan Geofisika [internet]. [diunduh pada 2018 Des 11]. Tersedia pada: http://dataonline.bmkg.go.id/akses_data.

Bradl HB. 2005. Heavy metals in the environment. Netherland (ND): Elsevier accademic Press.

Cappenberg HAW. 2008. Beberapa aspek biologi kerang hijau Perna viridis Linnaeus 1758. Oseana. 33(1): 33-40.

Copernicus Marine Service [internet]. [diunduh pada 2018 Des 11]. Tersedia pada: https://resources. marine.copernicus.eu/?option=com_csw\&task=res ults.
Cordova MR, Zamani NP, Yulianda F. 2011. Heavy metals accumulation and malformation of green mussel (Perna viridis) in Jakarta Bay Indonesia. Jurnal Moluska. 2(1): 1-8.

Eshmat ME, Mahasri G, dan Rahardja BS. 2014. Analisa kandungan logam berat timbal $(\mathrm{Pb})$ dan cadmium (Cd) pada kerang hijau (Perna viridis L.) di Perairan Ngemboh Kabupaten Gresik Jawa Timur. Jurnal IImiah Perikanan dan Kelautan. 6(1): 101-108.

Falah S, Pujiono WP, Agung S. Analisis logam berat $\mathrm{Cu}$ dan $\mathrm{Pb}$ pada air dan sedimen dengan kerang hijau ( $P$. Viridis) di Perairan Morosari Kabupaten Demak. Journal of Maquares. 7(2): 222-226.

Gobas FAPC, Wilcockson JB, Russel RW, Haffner GD. 1999. Mechanism of biomagnification in fish under laboratory and field conditions. Environmental Science \& Technology. 33(1): 133-141. https:// doi.org/10.1021/es980681m

Hutagalung HP. 2001. Mercury and cadmium content in green mussel, Mytilus viridis L. From Onrust Water, Jakarta Bay Creator. Bull. Env. Cont. And Tox. 42(6): 814-820. https://doi.org/10. 1007/BF01701620

Indirawati SM. 2017. Pencemaran logam berat Pb dan Cd dan keluhan kesehatan pada masyarakat di kawasan Pesisir Belawan. Jurnal JUMANTIK. 2(2): 54-60.

[KLH] Kementerian Lingkungan Hidup Republik Indonesia. 2004. Keputusan Menteri Negara Lingkungan Hidup Nomor 51 tentang Baku mutu air laut. Jakarta (ID).

Koropitan AF, Cordova MR. 2017. Study of heavy metal distribution and hydrodinamic simulation in green mussel culture net, Cilincing water-Jakarta Bay. Makara Journal of Science. 21(2) : 89-96. https://doi.org/10.7454/mss.v21i2.4406

Kusuma AH, Prartono T, Atmadipoera AS, Arifin T. 2015. Sebaran logam berat terlarut dan terendapkan di Perairan Teluk Jakarta pada bulan September 2014. Jurnal Teknologi Perikanan dan Kelautan. 6(1): 41-49. https://doi.org/ 10.24319/jtpk.6.41-49

Moriarty F. 1988. Ecotoxicology. The Study of pollutant in ecosystems. 2th ed. London (EN): Academic Press. 241p.

Munce G. 1990. Treat of Heavy metal in aquatic environment oceorance analysis and biologycal relevance. New York: Ul-Press.

$\mathrm{Ng}$ TYT, Wang WX. 2007. Interactions of silver, cadmium, and copper accumulation in green mussels (Perna viridis). Environmental Toxicology and Chemistry. 26(8) : 1764-1769. https://doi.org/10.1897/06-456R1.1 
Purba, C., Ridlo A., dan Suprijanto J. 2014. Kandungan logam berat $\mathrm{Cd}$ pada air, sedimen, dan daging kerang hijau (Perna viridis L.) di Perairan Tanjung Mas Semarang Utara. Journal of Marine Research. 3(3): 285-293.

Putra IA, Muslim, Sri YW. 2015. Studi kandungan Seng di air dan sedimen di Perairan Morosari Kecamatan Sayung, Kabupaten Demak. Jurnal Oseanografi. 4(2) : 457-461. https://doi.org/10.14710/jpk.4.1.6775

Riani E, Johari HS, Cordova MR. 2017. Bioakumulasi logam berat kadmium dan timbal pada kerang kapak-kapak di Kepulauan Seribu. JPHPI. 20(1) : 131-142.

https://doi.org/10.17844/jphpi.v20i1.16500

Rochyatun E, Rozak A. 2007. Pemantauan kadar logam berat dalam sedimen di Perairan Teluk jakarta. Makara Sains. 11(1) : 28-36. https://doi.org/10.7454/mss.v11i1.228

Sasikumar G, Krishnamoorthy M, Krishnakumar PK, Bhat GS. 2011. Accumulation of trace metals in green mussel Perna viridis in the shellfish harvesting environment along southern Karnataka coast. Indian Journal of Fisheries. 58(1) : 53-58.

Sudaryanto A, Muchtar M, Razak H, Tanabe S. 2005. Kontaminasi Organoklorin persisten dalam kerang hijau (Perna viridis) di Perairan Indonesia. Oseanologi dan Limnologi. 37 : 1-14.

Suprapti NH. 2008. Kandungan Chromium pada perairan, sedimen dan Kerang Darah (Anadara granosa) di Wilayah Pantai Selatan sekitar Muara
Sungai Sayung, Desa Morosari Kabupaten Demak, Jawa Tengah. BIOMA. 10(2) : 53-56. https://doi.org/10.14710/bioma.10.2.36-40

Suprapto, D, Suryanti S, Latifah N. 2018. Content heavy metal $\mathrm{Pb}, \mathrm{Cd}$ in Perna viridis and sediments in Semarang bay. Conference series: Earth and Environmental Science. https://doi.org/10.1088/1755-1315/116/1/012078

Suryono CA, Djunaedi A. 2017. Logam berat $\mathrm{Pb}, \mathrm{Cr}$ dan Cd dalam perairan Tanjung Mas Semarang. Jurnal Kelautan Tropis. 20(1):25-29. https://doi.org/10.14710/jkt.v20i1.1350

Thomas CA, Bendell-Young L. 1998. Lingking the sediment geochemistry of an intertidal region to metal bioavailability in the deposit feeder Macoma balthica. Marine Ecology Progress series. 173 : 197-213. https://doi.org/10.3354/meps 173197

USEPA. 2004. The incidence and severity of sediment contamination in surface waters of United States, National Sediment Quality Survey : Second edition EPA-823-R-04-2007,U.S., $\quad$ Environmental Protection Agency, Washington D.C.

Wang Z, Yan C, Kong A, Wu D. 2010. Mechanisms of cadmium toxicity to various trophic saltwater organisms. Nova Science Publishers.

Yu X, Yana Y, Wang W. 2010. The distribution and speciation of trace metals in surface sediments from the Pearl River Estuary and the Daya Bay, Southern China. Marine Pollution Bulletin 60, pp. 1364-1370. https://doi.org/10.1016/j.marpolbul.2010.05.012 